\title{
EFFECT OF CONTEXTUAL TEACHING AND LEARNING ON IMPROVING ABILITY OF MATHEMATICAL COMMUNICATIONS VIEWED FROM INTEREST LEVEL OF STUDENT LEARNING
}

\author{
Hoer Mutaqin ${ }^{1}$, Jejen Abdul Fatah², Nurkolis ${ }^{3}$ \\ ${ }^{1}$ SMK Negeri 1 Klari Karawang \\ ${ }^{2}$ SMA YWKA Bandung \\ ${ }^{3}$ MA Teladan Al-Kalam Cianjur \\ ${ }^{1}$ hoer.mutaqin@gmail.com, ${ }^{2}$ jen.adlfa@gmail.com, ${ }^{3}$ nurkolis1327@gmail.com
}

\begin{abstract}
This study aims to obtain a picture of improving the ability of mathematical communication on the implementation of learning contextual teaching and learning approach viewed from the level of student learning interest. The method used in this research is experiment with factorial design $3 \times 2$. The population is all junior high school students in Karawang regency with the subject of the sample is two classes of X in one of SMP Negeri in Kabupaten Karawang. The first class gets learning with contextual teaching and learning learning, and the second class gets learning by direct learning. From the research, it can be concluded that there are differences in the mathematical communication ability of the students whose learning using Contextual Teaching and Learning learning with direct learning, there is no difference in the improvement of mathematical communication ability among students who have high, medium and low learning interest, there is an interaction between the learning approach and the level interest in learning to improve the ability of mathematical communication, the implementation of learning using Contextual Teaching and Learning learning has been running with the steps that have been determined, the students' difficulties in completing the problem of understanding and mathematical communication lies in the indicator (a) linking a concept / principle with the con cept / principle (b) can apply formulas in simple calculations and work on algorithmic calculations, (c) associate a concept / principle with other concepts / principles.
\end{abstract}

Keywords: Mathematical Communication, Interest in Learning, Contextual Teaching and Learning

\begin{abstract}
Abstrak
Penelitian ini bertujuan untuk memperoleh gambaran tentang peningkatan kemampuan komunikasi matematik pada implementasi pembelajaran dengan pendekatan contextual teaching and learning ditinjau dari tingkat minat belajar siswa. Metode yang digunakan penelitian ini adalah eksperimen dengan desain factorial $3 \times 2$. Populasinya adalah seluruh siswa SMP di Kabupaten Karawang dengan subjek sampelnya adalah dua kelas X di salah satu SMP Negeri di Kabupaten Karawang. Kelas pertama mendapat pembelajaran dengan pembelajaran contextual teaching and learning, dan kelas kedua mendapat pembelajaran dengan pembelajaran langsung. Dari penelitian diperoleh kesimpulan bahwa terdapat perbedaan kemampuan komunikasi matematik siswa yang pembelajarannya menggunakan pembelajaran Contextual Teaching and Learning dengan pembelajaran langsung, tidak terdapat perbedaan peningkatan kemampuan komunikasi matematik antara siswa yang mempunyai minat belajar high, medium, dan low, terdapat interaction antara pendekatan pembelajaran dengan tingkat minat belajar terhadap peningkatan kemampuan komunikasi matematik, implementasi pembelajaran menggunakan pembelajaran Contextual Teaching and Learning sudah berjalan dengan langkah-langkah yang telah ditetapkan, kesulitan siswa dalam menyelesikan soal pemahaman dan komunikasi matematik terletak pada indikator (a) mengaitkan suatu konsep/prinsip dengan konsep/prinsip lainnya, (b) dapat menerapkan rumus dalam perhitungan sederhana dan mengerjakan perhitungan secara algoritmik, (c) mengaitkan suatu konsep/prinsip dengan konsep/prinsip lainnya.
\end{abstract}

Kata Kunci: Komunikasi Matematik, Minat Belajar, Contextual Teaching and Learning 

Improving Ability Of Mathematical Communications Viewed From Interest Level Of Student Learning

How to Cite: Mutaqin,H., Fatah,J.A., Nurkolis..(2018). Effect Of Contextal Teaching And Learning On Improving Ability Of Mathematical Communications Viewed From Interest Level Of Student Learning. JIML, 1 (2), 75-84.

\section{INTRODUCTION}

Mathematics is a universal science that underlies the development of modern technology, has an important role in various disciplines and develop human mindset Mathematics learning activities have an important role to develop the skills and skills of reasoning and shape the attitude of learners. In order to achieve the goal of developing thinking power is expected learners have the knowledge and skills in the field of mathematics that he studied. according to Sumarmo (2015) There are five main competencies in mathematics that must be possessed by students: mathematical understanding, mathematical problem solving, mathematical communication, mathematical connection, and mathematical reasoning.

One of the learners' abilities that need to be developed is also the ability of mathematical communication. According to Baroody (Umar, 2012) there are at least 2 important reasons that make communication in learning mathematics need to be the focus of attention that is (1) mathematics as language; mathematics is not just a tool to aid thinking, a tool for finding patterns, or solving problems but also maths "an invaluable tool for communicating a variety of ideas clearly, precisely, and succintly," and (2) mathematics learning as social activity; as a social activity, in mathematics learning, interaction between students, as well as gurusiswa communication is an important part for "nurturing children's mathematical potential" .. This is supported by the opinion Sumarmo (2015)

"The ability of mathematical communication also conforms to the essence of mathematics as an efficient, meaningful, symbolic language of symbols of beautiful order and quantitative analytical capabilities, is unuversal and understandable to everyone anytime and anywhere, and helps produce the mathematical model necessary for solving masalh various branches of science and everyday life issues."

Later in the early 20th century, Dewey in 1913 discussed the importance of interest and proposed two factors in building interest: identification and application. Dewey argues that if the student recognizes and identifies himself with learning activities, he will devote all his attention to the learning process. Therefore, Dewey proposes that a better way to teach is to arouse the interests of learners rather than forcing learners to work hard.

Responding to this, researchers intend to use effective learning and assessed to improve the quality of mathematical communication and interests of learners .. A learning approach that allows the learning process that applies students' understanding and communication skills in various contexts, inside and outside the classroom, for solve real problems or simulated problems, either individually or in groups, and can grow the reinforcement of the concept known as the contextual approach.

This is reinforced by Suherman (2003) argues, "Contextual Teaching and Leaning (CTL) learning is learning that begins by taking (simulating, telling, dialogue, or questioning) events in the real world of everyday life which students experience later raised into the concept discussed ". 
The purpose of this study is to obtain an overview of the mathematical communication ability of the students studying with Contextual Teaching and Learning and direct learning by considering the level of their learning interest.

\section{METHOD}

The method of this study was quasi experiments, with researchers taking two classes for the research sample. First class gets learning with metaphorical thinking approach, and second class gets direct learning. Before and after the treatment of both classes were given the same treatment of the ability of mathematical understanding. With the factorial design as follows:

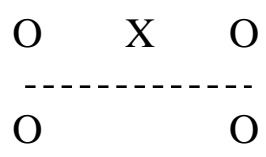

Note :

$\mathrm{O}:$ Pretest $=$ postest mathematical communication ability

$\mathrm{X}$ : contextual teaching anda learing approach

- - - : The sampling is not subject random

The population in this study is junior high school students in Karawang regency. With the subject of the sample are two classes VII students in one State Junior High School in Karawang regency.

The data that is processed and analyzed in this research is pretest and posttest data of students 'comprehension and mathematical communication and students' learning interest. The data will be used as a benchmark to answer the hypothesis in this study. The resulting data is quant itative data and data processing is done by using SPSS Software (Statistical Product and Service Solution) version 21.0 for Windows. .

\section{RESULTS AND DISCUSSION}

\section{Results}

The improvement of students' mathematical communication ability can be seen by analyzing the normalized gain index data (n gain) obtained from pretest and posttest result.The $n$-gain data of students' mathematical communication skills associated with the level of learning interest are presented in Table 4.7 below.

Table 1. Improvement of Mathematical Communication Skills Judging from the Interest Level of Student Learning

\begin{tabular}{|c|c|c|c|}
\hline \multicolumn{4}{|c|}{ Approa } \\
\hline \multirow{4}{*}{ 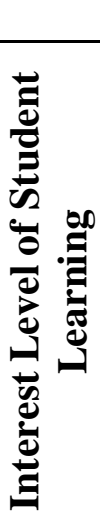 } & & CTL & DI \\
\hline & 氙 & $\begin{array}{c}.84 ; .73 ; .63 ; .55 ; .76 ; .75 ; .61 ; .75 \\
.83 ; .79 \\
.90\end{array}$ & $\begin{array}{c}.88 ; .81 ; .75 ; .71 ; .68 ; .68 ; .67 ; .63 ; \\
.60 ; .57 ;\end{array}$ \\
\hline & : & $\begin{array}{c}.59 ; .63 ; .63 ; .61 .75 ; .72 ; .71 ; .84 ; \\
.50 ; .77 ; .74 ; .67 ; .60 ; .63 ;\end{array}$ & $\begin{array}{l}.68 ; .68 ; .67 ; .67 ; .63 ; .60 ; .60 ; .58 ; \\
.56 ; .53 ; .52 ; .52 ; .50 ; .38 ; .35 ; .33 ;\end{array}$ \\
\hline & $\stackrel{3}{9}$ & $\begin{array}{c}.52 ; .53 ; .52 ; .50 ; .71 ; .65 ; .50 ; .68 \\
.58 ; .50 ; .50\end{array}$ & $\begin{array}{c}.67 ; .67 ; .64 ; .63 ; .62 ; .60 ; .57 ; .57 ; \\
.52 ; .47 ; .44\end{array}$ \\
\hline
\end{tabular}



Improving Ability Of Mathematical Communications Viewed From Interest Level Of Student Learning

Table 1. is required to test the hypotheses in this study, namely: (a) There is a difference peningakatan ability of mathematical communication between students who obtained learning Contextual Teaching and Learning with who obtained direct learning (b)There is a difference in the improvement of mathematical communication ability among students whose level of interest is: high, medium, low (c). There is an interaction effect between the learning model and the level of student's interest in improving students' mathematical communication ability.

The details of the descriptive statistical analysis of the $n$ gain data are presented in Table 2 . below.

Table 2. Descriptive Statistics of N-Gain Data Mathematical Communication

\begin{tabular}{ccccc}
\hline Approach & Max. Value & Min.Value & Mean & $\begin{array}{c}\text { Standard } \\
\text { Deviation }\end{array}$ \\
\hline$C T L$ & .90 & .50 & .6589 & .1139 \\
DI & .88 & .33 & .5995 & .1151 \\
\hline
\end{tabular}

Based on Table 2. it can be seen that the n-gain class that obtains contextual learning ranges from 0.50 to 0.90 and the overall $n$-gain average is in the medium criterion. While the $n$-gain class that gained direct learning ranged from .33 to .88 and the overall $\mathrm{n}$-gain average was in the medium criterion. In addition, we can see that the average n-gain of the two classes is different, with a difference of .0594. Descriptively, the improvement of mathematic communication ability of students who get a contextual learning model is better than those who get direct learning.

To determine whether the difference in communication skills improvement in the two classes differed significantly or not, statistical tests should be performed. Two-way ANOVA test results with SPSS 21 can be seen in Table 3 below.

Table 3. Results of Anova Two Path Test of Gain Mathematical Communication

\begin{tabular}{lrrrrr}
\hline Source & $\begin{array}{c}\text { Type III Sum } \\
\text { of Squares }\end{array}$ & Df & Mean Square & \multicolumn{1}{c}{ F } & Sig. \\
\hline Corrected Model &, $380^{\mathrm{a}}$ & 5 &, 076 & 8,269 &, 000 \\
Intercept & 28,550 & 1 & 28,550 & 3105,050 &, 000 \\
Medel_Pembelajaran &, 041 & 1 &, 041 & 4,428 &, 039 \\
Tingkat_Minat &, 251 & 2 &, 125 & 13,639 &, 000 \\
Medel_Pembelajaran * &, 063 & 2 &, 032 & 3,443 &, 038 \\
Tingkat_Minat & & & & & \\
Error &, 616 & 67 &, 009 & & \\
Total & 29,857 & 73 & & & \\
Corrected Total &, 996 & 72 & & & \\
\hline
\end{tabular}

The first will be seen the influence of contextual learning model and direct learning to improve students' mathematical communication ability. From Table 3. obtained Sig value. $=.039$, in other words Sig. $<.05$. This resulted in $\mathrm{H} 0$ rejected, meaning there is a significant difference between the improvement of mathematical communication skills between students who obtained a contextual learning model and direct learning at $5 \%$ significance level. When viewed from the average of learning outcomes using contextual model is greater than direct learning. 
The implication of learning using contextual model in mathematical communication ability is more effective than direct learning.

Next will be seen the influence of the level of student interest in learning to improve student communication skills. From table 3. obtained Sig value. $=.000$, in other words Sig. $<.05$. This results in $\mathrm{HO}$ being rejected, meaning that there is at least one group of students with a certain level of learning interest whose students' mathematical communication ability is significantly different with other level of learning interest at 5\% significance level.

To find out which groups of students with different learning interests differ significantly in improving mathematical communication skills, followed by Scheffe test. The results are presented in Table 4. below.

Table 4. Scheffe Test Results N-Gain Mathematical Communication Skills

\begin{tabular}{|c|c|c|c|c|c|c|}
\hline \multirow{2}{*}{$\begin{array}{l}\text { (I) Level of } \\
\text { Learning } \\
\text { Interest }\end{array}$} & \multirow{2}{*}{$\begin{array}{l}\text { (J) Level of } \\
\text { Learning } \\
\text { Interest }\end{array}$} & \multirow{2}{*}{$\begin{array}{c}\text { Mean } \\
\text { Difference } \\
(\mathbf{I}-\mathbf{J}) \\
\end{array}$} & \multirow{2}{*}{$\begin{array}{c}\text { Std. } \\
\text { Error }\end{array}$} & \multirow[t]{2}{*}{ Sig. } & \multicolumn{2}{|c|}{$\mathbf{9 5 \%}$ Confidence Interval } \\
\hline & & & & & Lower Bound & Upper Bound \\
\hline \multirow{2}{*}{ High } & Medium &, $1137^{*}$ & 02728 & ,000 & ,0483 & , 1791 \\
\hline & Low & $1477^{*}$ & 02925 & ,000 & 0776 & 2178 \\
\hline \multirow{2}{*}{ Medium } & High &,$- 1137^{*}$ &, 02728 &, 000 &,- 1791 &,- 0483 \\
\hline & Low & 0341 & 02692 & , 420 &,- 0305 & 0986 \\
\hline \multirow{2}{*}{ Low } & High &,$- 1477^{*}$ & 02925 & ,000, &,- 2178 &,- 0776 \\
\hline & Low &,- 0341 & 02692 & , 420 &,- 0986 & 0305 \\
\hline
\end{tabular}

From Table 4. it can be concluded that there is a significant difference between the improvement of students' mathematical communication ability on the level of high learning interest toward the level of medium learning interest $(\mathrm{Sig}=.000, \mathrm{Sig} .<.05)$ at $5 \%$ significance level. There is also a significant difference between improving students' mathematical communication ability at high learning interest level to low learning interest level ( Sig $=.000, \mathrm{Sig} .<.05)$ at $5 \%$ significance level. In addition, there was a significant difference between the improvement of students' mathematical communication ability on the level of moderate learning interest to low learning interest level ( $\mathrm{Sig}=.042$, Sig. $<.05)$ at $5 \%$ significance level. In this case, the improvement of students' mathematical communication ability with high learning interest level and the level of learning interest is better than the students with low learning interest level. The implication, the improvement of students' mathematical communication ability at the level of high and medium learning interest is more developed than the students whose level of learning interest is low.

Furthermore, it will be seen the effect of interaction jointly between the learning model and the level of interest in learning to improve students' mathematical communication skills. From Table 3. obtained Sig value. $=.038$, in other words Sig. $<.05$. This resulted in H0 being rejected, meaning that there is interaction of learning model of CTL with interest between the difference of improvement of mathematic communication ability of students who gain learning with contextual model at high, medium and low learning interest level with students who gain direct learning at high, low at $5 \%$ significance level. 
80 Mutaqin,H., Fatah,J.A., Nurkolis.. Effect Of Contextal Teaching And Learning On Improving Ability Of Mathematical Communications Viewed From Interest Level Of Student Learning

Table 5. Tests of Between-Subjects Effects

\begin{tabular}{lrrrrr}
\hline Source & $\begin{array}{c}\text { Type III Sum } \\
\text { of Squares }\end{array}$ & Df & Mean Square & \multicolumn{1}{c}{ F } & Sig. \\
\hline Corrected Model &, $380^{\text {a }}$ & 5 &, 076 & 8,269 &, 000 \\
Intercept & 28,550 & 1 & 28,550 & 3105,050 &, 000 \\
Interaction &, 380 & 5 &, 076 & 8,269 &, 000 \\
Error &, 616 & 67 &, 009 & & \\
Total & 29,857 & 73 & & & \\
Corrected Total &, 996 & 72 & & & \\
\hline
\end{tabular}

a. R Squared $=, 382$ (Adjusted R Squared $=, 335)$

The table above shows that between the four combinations in the interaction variable indicates a significant value $(F=8.269$; Sig. $<0.05)$. Because significant then we continue to look into the Multiple Comparisons or post hoc. If the analysis of variance above we only know there are differences in the improvement of students' mathematical communication skills in terms of the level of interest in learning and learning methods only, then the post hoc we can see in detail.

Table 6. Multiple Comparison Test between Learning Methods and Level of Learning Interest.

\begin{tabular}{|c|c|c|c|c|c|c|}
\hline $\begin{array}{l}\text { (I) } \\
\text { interaction }\end{array}$ & $(\mathrm{J})$ interaction & $\begin{array}{c}\text { Mean } \\
\text { Difference (I- } \\
\text { J) }\end{array}$ & $\begin{array}{c}\text { Std. } \\
\text { Error }\end{array}$ & Sig. & $\begin{array}{l}95 \% \text { Confide } \\
\text { Lower } \\
\text { Bound } \\
\end{array}$ & $\begin{array}{l}\text { e Interval } \\
\text { Upper } \\
\text { Bound }\end{array}$ \\
\hline \multirow{5}{*}{ CTL high } & CTL medium &, 0420 & ,04190 & ,961 &,- 1017 & 1857 \\
\hline & CTL low & ,0693 & 03863 & ,668 &,- 0632 & ,2018 \\
\hline & DI high & $1900^{*}$ & 03756 &, 000 &, 0612 & ,3188 \\
\hline & DI Medium & $1773^{*}$ & 04089 & ,005 & 0371 & ,3175 \\
\hline & DI low & $1582^{*}$ & ,04089 & ,017 & 0180 & 2984 \\
\hline \multirow{5}{*}{$\begin{array}{l}\text { CTL } \\
\text { medium }\end{array}$} & CTL high &,- 0420 & 04190 & 961 &,- 1857 & 1017 \\
\hline & CTL low & ,0273 & 03970 & ,993 &,- 1089 & 1634 \\
\hline & DI high & $1480^{*}$ & ,03865 & 019 & 0155 & 2805 \\
\hline & DI Medium &, 1353 & ,04190 & ,078 &,- 0084 & 2789, \\
\hline & DI low &, 1162 & 04190 & 190 &,- 0275 & 2598 \\
\hline \multirow{5}{*}{ CTL low } & CTL high &,- 0693 & 03863 & ,668 &,- 2018 & 0632 \\
\hline & CTL medium &,- 0273 & ,03970 & ,993 &,- 1634 & 1089 \\
\hline & DI high &, $1207^{*}$ & 03509 & ,049 & ,0004 & 2410 \\
\hline & DI Medium & 1080 & 03863 & 183 &,- 0245 & 2405 \\
\hline & DI low & ,0889 & 03863 & ,391 &,- 0436 & 2214 \\
\hline \multirow{5}{*}{ DI high } & CTL high &,$- 1900^{*}$ & 03756 &, 000 &,- 3188 &,- 0612 \\
\hline & CTL medium &,$- 1480^{*}$ & 03865 & 019 &,- 2805 &,- 0155 \\
\hline & CTL low &,$- 1207^{*}$ & ,03509 & ,049 &,- 2410 &,- 0004 \\
\hline & DI Medium &,- 0127 & ,03756 & 1,000 &,- 1415 & 1161 \\
\hline & DI low &,- 0318 & ,03756 & ,981 &,- 1606 & ,0970 \\
\hline \multirow{5}{*}{$\begin{array}{l}\text { DI } \\
\text { Medium }\end{array}$} & CTL high &,$- 1773^{*}$ & ,04089 & ,005 &,- 3175 &,- 0371 \\
\hline & CTL medium &,- 1353 & ,04190 & ,078 &,- 2789 & 0084 \\
\hline & CTL low &,- 1080 & ,03863 &, 183 &,- 2405 & 0245 \\
\hline & DI high & 0127 & ,03756 & 1,000 &,- 1161 & , 1415 \\
\hline & DI low &,- 0191 & 04089 & ,999 &,- 1593 & 1211 \\
\hline \multirow{2}{*}{ DI low } & CTL high &,$- 1582^{*}$ & ,04089 & ,017 &,- 2984 &,- 0180 \\
\hline & CTL medium &,- 1162 & ,04190 & , 190 &,- 2598 & 0275 \\
\hline
\end{tabular}




\begin{tabular}{|c|c|c|c|c|c|c|}
\hline \multirow[t]{4}{*}{$\begin{array}{l}\text { (I) } \\
\text { interaction }\end{array}$} & $(\mathrm{J})$ interaction & $\begin{array}{c}\text { Mean } \\
\text { Difference (I- } \\
\text { J) }\end{array}$ & $\begin{array}{c}\text { Std. } \\
\text { Error }\end{array}$ & Sig. & $\begin{array}{l}\text { 95\% Confide } \\
\text { Lower } \\
\text { Bound }\end{array}$ & $\begin{array}{l}\text { e Interval } \\
\text { Upper } \\
\text { Bound }\end{array}$ \\
\hline & CTL low &,- 0889 & ,03863 & ,391 &,- 2214 & ,0436 \\
\hline & DI high & ,0318 & ,03756 & ,981 &,- 0970 & , 1606 \\
\hline & DI Medium & 0191 & ,04089 & ,999 &,- 1211 & ,1593 \\
\hline
\end{tabular}

The above results show that: (1) There is a significant difference in the increase of mathematical communication ability between the improvement of high contextual communication ability with high DI (Sig..000), medium DI (Sig. .005), and low DI (Sig. .017); (2) There is no difference in the improvement of mathematical communication ability which is significant on contextual high with medium contextual (Sig .961) and low contextual (.668); (3) There is a significant difference in communication skill in medium contextual context with high DI (Sig .019); (4) There was no significant difference in the ability of mathematical communication in the low contextual contextual group (Sig .993), moderate DI (Sig .078) and low DI (.190); (5) There is a significant difference in communication skill improvement in low contextual group with high DI (Sig .049); (6) There was no significant difference in communication ability improvement in low contextual group with moderate DI (Sig .183) and low DI (Sig .393); (7) There was no significant difference in the increase of mathematical communication ability in high DI group with moderate DI (Sig 1,000) and low DI (Sig .981); (8) There was no significant difference in the increase of mathematical communication ability in the moderate DI group with low DI (Sig .999).

Here are the graphs generated from the analysis:

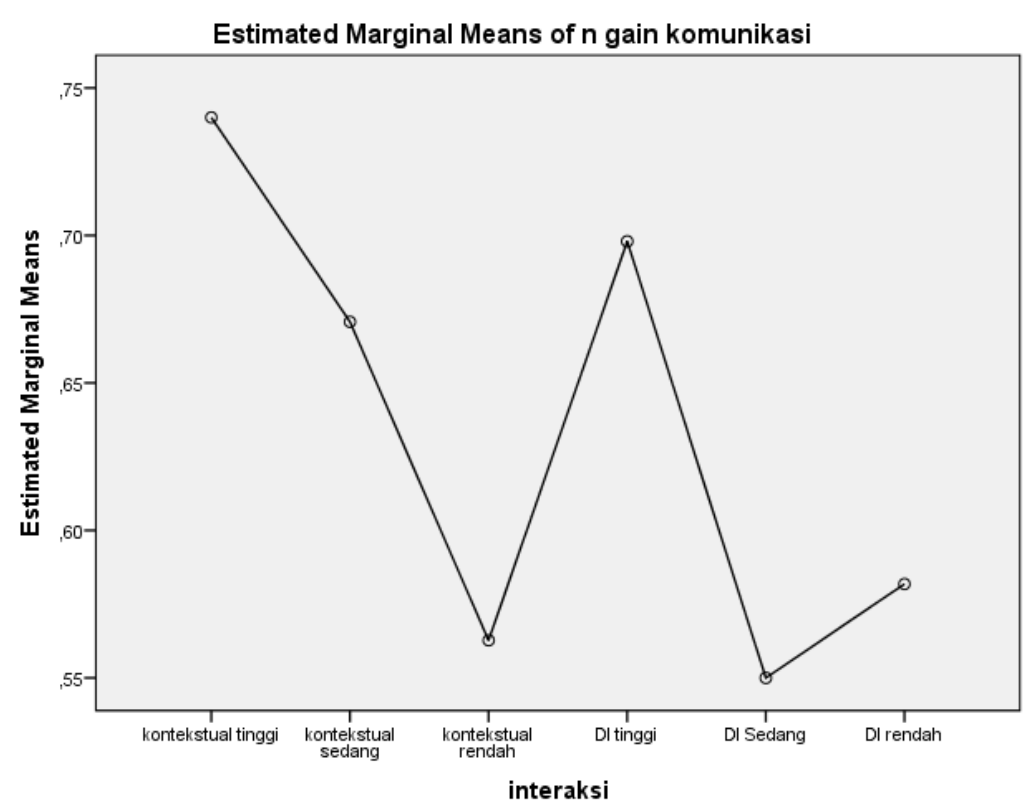

Figure 1. Differences Improved mathematical communication skills Based on Learning Method and Interest Interest Level

Overall the results of the analysis show that the success of the learning method depends on the level of interest in learning. With the interaction, we can not simply conclude that the improvement of mathematical communication ability in the students who get the contextual learning approach is better than the DI approach, but depends on the level of learning interest. Contextual learning approaches are more effective at high learning interest levels as well as 
more effective DI approaches to high learning interest levels Overall analysis results show that the success of learning methods depends on the level of interest in learning. With the interaction, we can not simply conclude that the improvement of mathematical communication ability in the students who get the contextual learning approach is better than the DI approach, but depends on the level of learning interest. Contextual learning approaches are more effective at high learning interest levels as well as more effective DI approaches to high learning interest levels.

\section{Discussion}

Increased student learning outcomes are seen in the N-gain of mathematical communication ability which shows the improvement of student learning outcomes after the learning done on the class using contextual learning (CTL) has an average of .50, whereas in the class using the learning with direct learning has the average, average .33. It can be concluded that the $\mathrm{N}$-gain of mathematical communication ability in the class using contextual learning (CTL) is greater than the $\mathrm{N}$-gain of mathematical communication ability in the class using learning by direct learning. This is in line with research conducted by Triana with the title "Improving the Ability of Understanding and Communication Mathematics and Interests of High School Students Using Contextual Approach" shows that the improvement of students 'mathematical communication skills using learning with contextual approach is better than the achievement and improvement of students' mathematical communication skills with DI.

Based on the $\mathrm{N}$-gain data analysis of mathematical communication ability, both groups are normally distributed. This is shown in the normality test results of N-Gain data listed above. Karana value sig. taken from column Kolmogorov-Smirnov for both groups more than .05, then $\mathrm{H} 0$ is accepted or in other words the data of the two groups are normally distributed. It was also shown that the data variance of the two homogeneous groups, as shown in the homogeneity test of N-Gain data above. Because the value of sig. more than .05, then $\mathrm{H} 0$ is received or in other words the variance of both groups of homogeneous classes. Because the samples were taken from the normal and homogeneous distributed population, the data analysis test with Anova Dua Lane. The hypothesis test results are listed above. The sig value. for the learning model is .039 and less than .05 then $\mathrm{H} 0$ is rejected or in other words there is a significant difference in the improvement of mathematical communication ability between students who get contextual learning (CTL) and direct learning. The level of student interest in this study has a significant influence on improving the ability of mathematical communication. This is indicated by the sig value. .000 and less than .05 , then $\mathrm{H} 0$ is rejected or in other words it can be concluded that the improvement of mathematical communication ability between students whose level of interest; high, medium, and low differ significantly.

Hypothesis testing about the interaction between the learning model and the level of student's learning interest in improving the mathematical communication ability was the null hypothesis accepted. This is indicated by the sig value. 038 and less than .05 , then $\mathrm{H} 0$ is rejected or in other words it can be concluded that there is interaction between the learning model and the level of student's interest in improving the ability of mathematical communication.

\section{CONCLUSION}

Based on the results of research, processing and data analysis and hypothesis testing, the researchers can obtain conclusions from this study as follows: There are differences in students' mathematical communication skills using learning learning Contextual Teaching and Learning with direct learning. Based on the average, the average experiment class is higher than the 
control class. there is a difference in the improvement of mathematical communication ability among students who have high, medium, and low learning interest. there is an interaction between the learning approach and the level of interest in learning to improve the ability of mathematical communication.

\section{REFERENCES}

Arikunto, Suharsimi. (2009). Dasar-dasar Evaluasi Pendidikan. Jakarta: Bumi Aksara

Arikunto, Suharsimi. (2010). Prosedur Penelitian Suatu Pendekatan Praktik. Jakarta: Rineka Cipta

Depdiknas. (2002). Model-model Pembelajaran Matematika. Jakarta. Depdiknas.

Direktorat Pembinaan SMA. (2010). Panduan Pelaksanaan KTSP dalam Penyusunan Butir Soal. Modul: Kemendiknas. Tidak diterbitkan.

Juhara dan zauhara, D. M. (1999). Analisis Kualitas Alat evaluasi matematika. Hand out.

Bandung: Local education Canter (LEC).

Kemendikbud. (2011). Panduan Pelaksanaan Pendidikan Karakter. Jakarta

Qodariyah dan Hendriana. (2015). Mengembangkan Kemampuan Komunikasi dan Diposisi Matematik Siswa SMP Melalui Discovery Learning. Tesis IKIP Siliwangi Bandung: Tidak dipublikasikan

Rusman. (2010). Model-model Pembelajaran Mengembangkan Profesionalisme Guru. Jakarta: Rajawali Pers

Russefendi, E.T. (2005). Dasar-dasar Penelitian Pendidikan dan Bidang Non-Eksakta Lainnya. Bandung: Tarsito.

Russefendi, E.T. (2006). Pengantar kepada Membantu Guru Mengembangkan Kompetensinya dalam Pengajaran Matematika untuk Meningkatkan CBSA. Bandung: Tarsito.

Sabandar, Jozua. (2003). Pendekatan CTL dalam Pembelajaran Matematika. Bandung: Tidak dipublikasikan.

Sariningsih. (2014). Pendekatan CTL untuk Meningkatkan Kemampuan Pemahaman Matematis Siswa SMP. Tesis IKIP Siliwangi Bandung: Tidak dipublikasikan

Sudjana. (2005). Metoda Statistika. Bandung: Tarsito.

Suherman, Erman. (2003). Evaluasi Pembelajaran Matematika. Bandung: JICA.

Sumarmo, Utari. (2015). “Kumpulan Makalah Berpikir dan Disposisi Matematik Serta Pembelajarannya". Bandung: Jurusan Pendidikan Matematika FPMIPA UPI.

Suprijono, Agus. (2011). Cooperative Learning. Yogyakarta: Pustaka pelajar 
84 Mutaqin,H., Fatah,J.A., Nurkolis.. Effect Of Contextal Teaching And Learning On Improving Ability Of Mathematical Communications Viewed From Interest Level Of Student Learning

Triana, Neni R. (2017). Meningkatkan Kemampuan Pemahaman dan Komunikasi Mtematik serta Minat Belajar Siswa SMA Menggunakan Pendekatan CTL. Tesis IKIP Siliwangi Bandung: Tidak dipublikasikan

Trianto. (2010). Mendesain Model Pembelajaran Inovatif-Prograsif. Jakarta: Kencana.

Umar, Wahid (2012). Membangun Kemampuan Komunikasi Matematis dalam Pembelajaran Matematika. Jurnal Ilmiah Program Studi Matematika STKIP Siliwangi Bandung. 1(1) 1.

Widaningsih, Dedeh. (2009). Telaah Kurikulum Matematika Sekolah. Diktat Kuliah. Tasikmalaya: PSPM FKIP UNSIL. Tidak diterbitkan

Zevika, M., Yarman, Yerizon. (2012). Meningkatkan Kemampuan Pemahaman Konsep Siswa Kelas VIII SMP Negeri 2 Padang Panjang Melalui Pembelajaran Kooperatif Tipe Think Pair Share Disertai Peta Pikiran. Jurnal Pendidikan Matematika. 1(1).45-50 